Dialectologia 24 (2020), 253-272.

ISSN: 2013-2247

Received 17 March 2018.

Accepted 30 June 2018.

\title{
TRANSMISSION OF HAKKA TRADITIONAL KNOWLEDGE FROM TWO REVITALIZATION PROJECTS IN THAILAND: WHAT DID THEY ACHIEVE? ${ }^{1}$
}

\author{
Siripen UNGSITIPOONPORN \\ Mahidol University * \\ siripen.ung@mahidol.edu
}

Abstract

The phenomenon of intermarriage and assimilation into Thai society has contributed to diminishing Hakka language use. However, some elderly Hakka speakers have acknowledged this situation and are trying to preserve the Hakka language and culture as much as possible. Two research projects of Hakka language preservation and revitalization were conducted using Participatory Action Research (PAR) approach by the participants and researchers. The results were that in the first project, the adult generation had the ability to teach the traditional Hakka food style, but there were no Hakka children to learn from them. Several factors, such as fast food, climate change, and young people going to study outside the community, had an effect on language revitalization and preservation. Results from the second project showed that volunteer participants, Hakka association networks and internet communication are positive factors for language revitalization. Young people had opportunities to hear and speak Hakka with the elderly in the events if these were mainly organized occasions. Some participants collected data from Hakka speakers while others wrote articles related to their family history which they wanted to record and

\footnotetext{
${ }^{1}$ I would like to acknowledge with thanks Dr. Julia Sallabank's comments on the first draft on this manuscript. I acknowledge with thanks the help of Mary Chambers in copy-editing and proofreading this paper. This written paper was supported by British Council, Newton Fund, and Thailand research Fund under Researcher Links Travel Grant 2015/16.

** Research Institute for Languages and Cultures of Asia, Mahidol University, 999 Phutthamonthon Rd.4 Tambol Salaya, Amphoe Phutthamonthon, Nakhon Pathom, Thailand 73170.
} 
transfer to the next generation. As their knowledge of Hakka was limited, they wrote in the Thai language instead. From observation, most Hakka speakers know words from their language, but they cannot use them in full sentences. If someone could communicate in Hakka, they used mixed language with Thai.

\section{Keywords}

Hakka, language preservation, revitalization, transmission of traditional knowledge

\section{TRANSMISIÓN DEL CONOCIMIENTO TRADICIONAL DE HAKKA A PARTIR DE DOS PROYECTOS DE REVITALIZACIÓN EN TAILANDIA: ¿QUÉ SE LOGRÓ?}

\section{Resumen}

El fenómeno de los matrimonios mixtos y la asimilación en la sociedad tailandesa ha contribuido a disminuir el uso del idioma hakka. Sin embargo, algunos hablantes de hakka de edad avanzada han reconocido esta situación y están tratando de preservar el idioma y la cultura hakka tanto como sea posible. Dos proyectos de investigación sobre la preservación y revitalización de la lengua hakka fueron llevados a cabo utilizando el enfoque de Investigación de Acción Participativa (PAR) tanto por los participantes como por los investigadores. Los resultados mostraron que en el primer proyecto, la generación adulta tenía la capacidad de enseñar el estilo de comida tradicional hakka, pero no había niños hakka para aprender de ellos. Varios factores, como la comida rápida, el cambio climático y los jóvenes que van a estudiar fuera de la comunidad, tuvieron un efecto en la revitalización y preservación del lenguaje. Los resultados del segundo proyecto mostraron que los participantes voluntarios, las redes de asociaciones de hakka y la comunicación por Internet son factores positivos para la revitalización del lenguaje. Los jóvenes tuvieron la oportunidad de escuchar y hablar hakka con los ancianos en los eventos si se trataba principalmente de ocasiones organizadas. Algunos participantes recopilaron datos de hablantes de hakka, mientras que otros escribieron artículos relacionados con su historia familiar que querían registrar y transferir a la próxima generación. Como su conocimiento de hakka era limitado, en su lugar escribieron en tailandés. Por observación, la mayoría de los hablantes de hakka saben palabras de su idioma, pero no pueden usarlas en oraciones completas. Si alguien podía comunicarse en hakka, usaba un lenguaje mixto con tailandés.

\section{Palabras clave}

hakka, preservación lingüística, revitalización, transmisión de conocimiento tradicional 


\section{Introduction}

The Chinese language belongs to the Sino-Tibetan family. It is normally divided into North and South dialects. Hakka or Kejia is one of six Chinese dialect groups in the south and Mandarin is the only one in the north. It can be summarized as Figure 1.

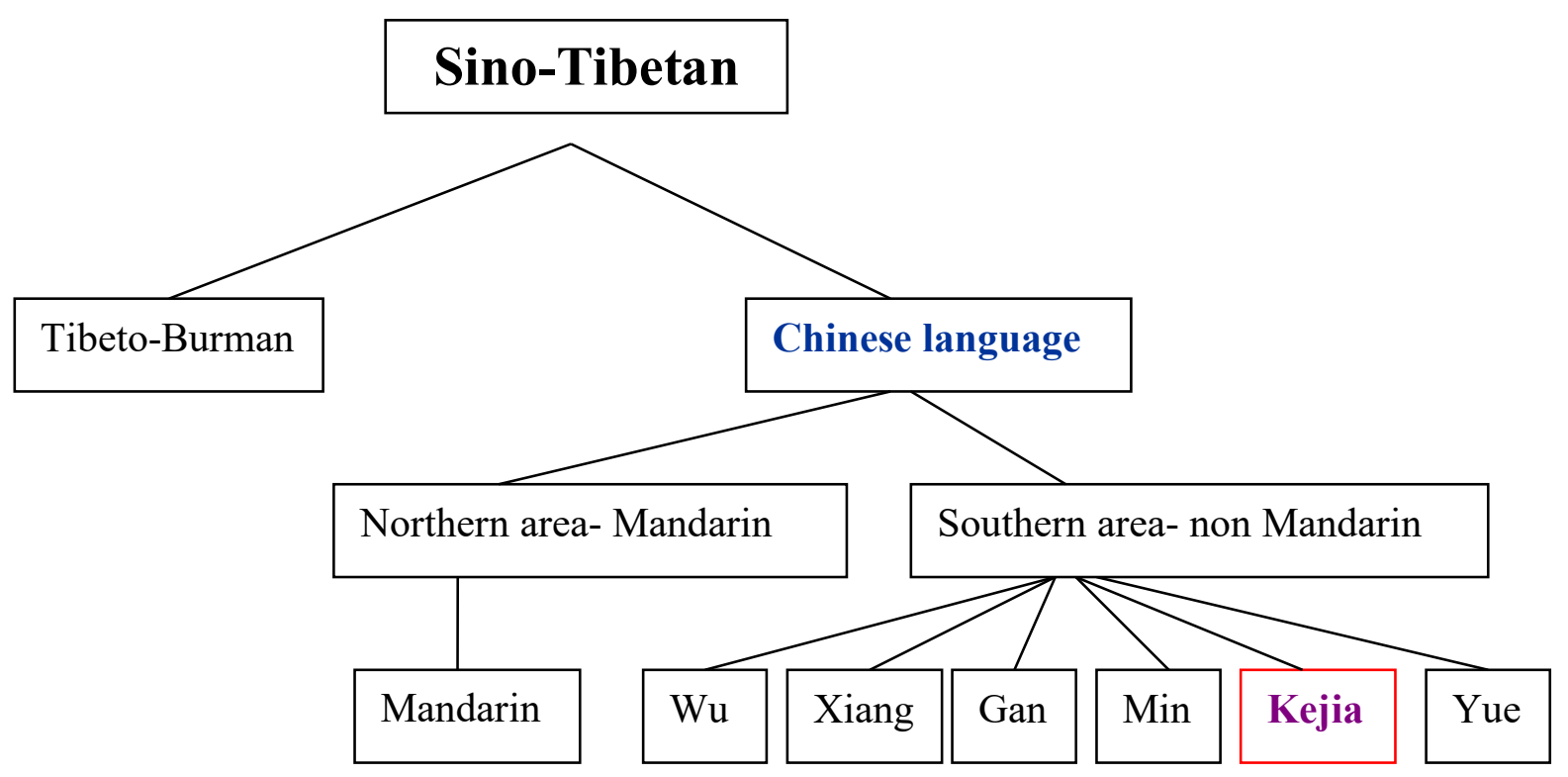

Figure 1. Sino-Tibetan language family tree (adapted from Luo 2005: 971 and Ungsitipoonporn 2007: 1).

Most Hakka descendants in Thailand came from Guangdong province, China, since the period spanning the reigns of the Thai kings Rama IV and Rama V (1868-1910). At present, they reside in every province, but are especially found in urban areas. From Ungsitipoonporn (2007), it was found that Hakka speakers in Thailand over the age of 50 can speak Hakka, but those under 50 can speak only a little Hakka. Furthermore, the younger generation cannot speak their mother tongue and in the worst case they know nothing about their ancestry. This is because of intermarriage and the parents not being aware of the history of their ancestors. This situation has led to the rapid decline of the Hakka language and culture. Fortunately, there are some elderly Hakka speakers who want to do something to preserve and revive it as much as possible. The key person 
known is Mr. Nopphadol Chawalkorn, ${ }^{2}$ a businessman, who intends to make the Hakka language well known among the Hakka youth (Ungsitipoonporn, 2011). He cooperated with Hakka scholars in Thailand, China and Taiwan to arrange conferences and activities in order to encourage Hakka descendants to learn about Hakka history. He hoped that he will find some Hakka speakers who are inspired to work with him to preserve the Hakka language.

\section{Language revitalization and preservation in Thailand}

In Thailand, there are about 70 living languages which belong to five language families, namely Austroasiatic, Tai-Kadai, Sino-Tibetan, Austronesian, and Hmong-Mien. However, at least fifteen languages are classified as endangered (Premsrirat 2007, 2010). They are Chong, Kasong, Samre, Chung, So (Thavung), Nyahkur, Mlabri, Lavua, Sakai, Mpi, Gong, Bisu, Moken, Urak Lawoc, and Saek. Major language groups in the border regions, such as Malayu, Northern Khmer, Mon, and Kuy, are also in a situation of language decline.

The Center for Documentation and Revitalization of Endangered Languages and Cultures, a unit of the Research Institute for Languages and Cultures of Asia, Mahidol University, was established in 2004 by Professor Suwilai Premsrirat. Linguists and facilitators of the center encourage the local people to do their own community-based research on the documentation and revitalization of their languages and culture as much as possible. For example, if languages have only oral language but no written form, linguists would co-operate with the local speakers to develop the writing system using Thai-based scripts. The speakers can then use the writing system as a tool for recording everything they want. Finally, they can transfer their local language and culture to the next generation. Therefore, linguists have a role in supporting community revival efforts if those ethnic groups want to keep their language alive. Many language groups do not understand and do not believe that their language is unsafe now. For example, the Mlabri

\footnotetext{
${ }^{2}$ He passed away $28^{\text {th }}$ September 2018.
} 
group is just a small number of speakers in Phrae and Nan provinces. At first, they insisted that their language is still used strongly, but when they found some evidence, like some significant items of vocabulary not being used by the younger generation, they accepted and understood why they have to preserve and revive their language and culture.

More than ten years of experience of language preservation and revitalization, Premsrirat summarized 11 steps of language revitalization, calling it the "Mahidol model", as follows:

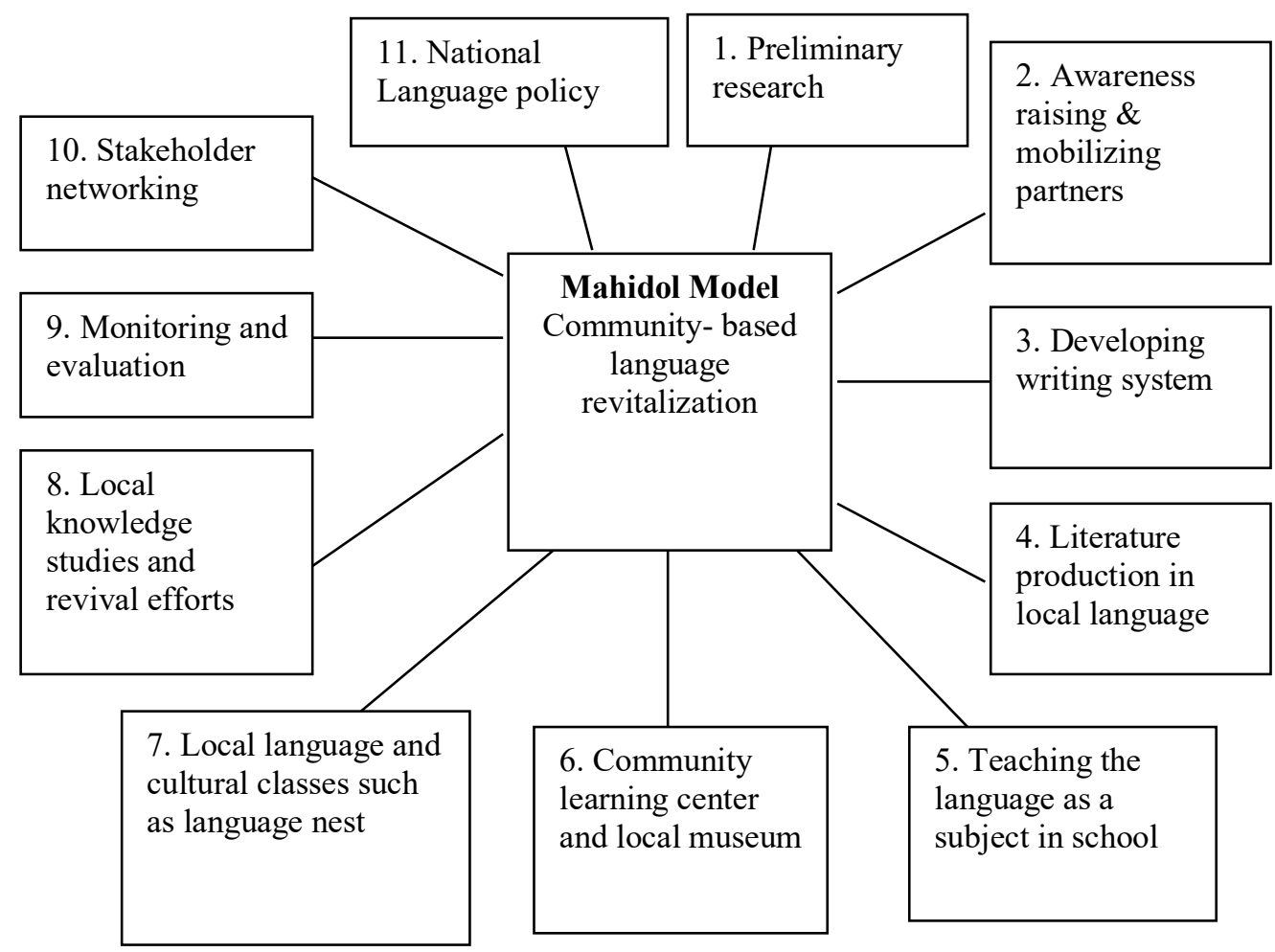

Figure 2. Mahidol model for language revitalization (adapted from Premsrirat 2012, 2017).

Since the beginning of the Hakka revitalization and preservation project, 3-4 tasks of Mahidol model have been followed, namely: basic research into phonology and grammar, awareness raising and mobilizing partners, local knowledge studies (history, dialects, food, custom, tradition), and expanding stakeholder networking. The other endangered ethnic groups follow similar tasks to those of the Mahidol model. The most common popular task is writing system development and literature production because these small 
ethnic groups have no writing systems. If they have a tool for writing the language down, they can write their traditional knowledge and then develop materials for distribution. The research results from Premsrirat and her team found that the most successful activity is orthography development for local languages using Thai-based scripts, not only for the ethnic groups who had no written language before, but also for groups who had a writing system previously, such as Mon, Northern Khmer, Tai Dam, etc. This is because the speakers are literate in Thai, the official language of Thailand. Everyone has to learn the Thai language in formal schooling and they can read and write in Thai. It is easier to learn their language when they write in Thai-based scripts because some phonemes are similar to Thai.

So far, the linguists and staff of the Center for Documentation and Revitalization of Endangered Languages and Cultures, Mahidol University, have worked with more than 20 ethnic groups in Thailand to develop writing systems based on Thai scripts. Some groups used these as a tool for recording local knowledge such as history, herb lore, folktales, music, ritual, etc. Some groups developed teaching materials and began teaching their languages as subjects in formal schools. Each ethnic group has different potential for revitalization in different areas, depending on how many fluent speakers there are and what the language situation is. In the case of Hakka, individuals used an informal writing system based on the Thai script for written communications among Hakka speakers. The writing system that they use is not systematic across speakers; this is a problematic issue when they write a narrative or message because Hakka is a tone language and has tone variation from dialect to dialect, so speakers do not agree on a systematic way of spelling the language.

\section{Why does the Hakka language and culture need to be preserved in Thailand?}

Linguists such as Joshua Fishman, Lenore Grenoble and Lindsay Whaley, and also UNESCO, have provided definitions of language status categories from the safest to the most unsafe or extinct. In this article, UNESCO's framework is used to classify the Hakka 
language of Thailand. UNESCO's language vitality and endangerment framework (Moseley 2007 ) is divided into six categories of language status, as follows:

1) Safe: language is spoken by all generations.

2) Vulnerable: most children speak the language, but it may be restricted to certain domains such as home.

3) Definitely endangered: children no longer learn the language as mother tongue in the home domain.

4) Severely endangered: the language is spoken by grandparents and older generation; the parent generation may be understand but do not speak to their children or even between themselves.

5) Critically endangered: the youngest speakers are grandparents and the elderly; they speak partially and infrequently.

6) Extinct: there are no speakers left.

From UNESCO's framework, the situation of Hakka language in Thailand is in category 4), severely endangered. It seems a normative phenomenon if there is nobody wants to do anything to protect the language or to make efforts to revive it. Fortunately, there are some Hakka elders who are trying to preserve Hakka language and culture. The Hakka group has confronted the crisis of language and culture because it was difficult to find fluent speakers with a lot of Hakka tradition knowledge to be consultants. The main informants of my research project from 2007 to 2012 were all over 60, with the best one being over 80 . The main reason is that the younger generation are automatically assimilated into the Thai culture and have no opportunities to use Hakka in their daily life; there are also no schools teaching the Hakka language. When they go to a formal school, they use only Thai as a medium of instruction and interpersonal communication. When they grow up and continue studying at a higher level, some of them move far away from their families, so that they have no opportunities to hear the language at all. Like other ethnic groups, if the language is lost, the local philosophy will be lost too. This 
phenomenon affects language diversity in Thailand. Therefore, this intangible heritage should be protected as much as possible.

After finishing her PhD in Linguistics, the author wanted to do research about the Hakka group so she applied for a grant to study the Hakka grammar further. In 2008, she started collecting data, including folk tales, personal narratives and conversations, for Hakka grammar analysis. She tried to find several key informants and finally met Mr. Nopphadol Chawalkorn, a businessman, who would like to encourage Hakka descendants to realize their Hakka origins (Ungsitipoonporn 2011). He spent a lot of time searching for information about the Hakka, and had had opportunities to exchange ideas with Hakka speakers such as the Hakka Association, the Hakka Society, etc. He introduced the researcher to some good Hakka speakers who still speak the Hakka language well and gave her a lot of useful data. Her research project would not have been complete if the researcher had not met these people. Furthermore, khun Nopphadol also introduced her to other Hakka people who would like to preserve the Hakka language, the important of them being khun Khanakorn Srimingmongkonkul, who is the webmaster of website www.hakkapeople.com. ${ }^{3}$ The researcher applied to become a member of this website. When the members communicated via the website, she got to know more Hakka people and found that there are several topics that Hakka people want to know more about. For example, who is Hakka, where did they come from, how to speak Hakka, etc. This website was beneficial because she was able to read members' posts and follow their discussions, acquiring information and knowledge of Hakka from the members (Ungsitipoonporn 2013). After meeting Hakka members several times, the researcher saw that these people had considerable knowledge of Hakka history, food, ritual, poetry, song, etc. Then she decided to persuade them to do research for Hakka preservation and revitalization. This "Hakka online community" is different from other ethnic groups in that there is no actual community. Instead, the researcher communicated through the website, where the members can write and post their opinions. However, if the researcher would like to communicate face to face, she can also organize both formal and non-formal events which allow us to become more closely acquainted and to know each other better. After

\footnotetext{
${ }^{3}$ Unfortunately, this website is inactive now but can access and read only because of some reasons of server and new technology.
} 
finishing her Hakka grammar project in 2012, the researcher was awarded further funding to continue her research with the Hakka people again.

\section{The research processes of the two projects on Hakka preservation and revitalization}

The two Hakka research projects that have already been finished were analyzed in terms of the outcomes achieved for both the researcher and the Hakka speakers. One project was "Local Food Revival for Food Security Enhancement and Ethnic Cultural Continuity" (Ungsitipoonporn 2014), and the other was "Culture for Sustainably Promoting and Transmitting Local Wisdom via the Online Community" (Ungsitipoonporn \& Laparporn 2016).

\subsection{Before starting the projects}

As Hinton (2001: 5-6) suggested, "The goals of a language revitalization program must depend on the situation in which the language finds itself. How large is the speech community? What kinds of resources are there? Are there still native speakers? What is the level of desire on the part of the community for language revitalization?". Therefore, the researcher started with several questions to be addressed before developing a research project for the Hakka group. These questions were as follows:

-Where is the best area to conduct research? Is there any village or community that still preserves the Hakka identity?

-What are the issues of language revitalization and preservation that are of interest to the Hakka speakers? Can they use the Hakka language for speaking and communication?

-How many Hakka people can be involved in the research project? Do they have enough time to work with the researchers?

-What is the research methodology?

-What are the benefits for this group? 
The researcher had to survey the possibilities, addressing these questions to the Hakka members of the website, who were her target group. One member said that there is a Hakka community located at Haui Krabok village, Ban Pong District, Ratchaburi Province. More than $90 \%$ of the population are Hakka speakers and they carry on Hakka traditions. There is an important Chinese shrine in the community called [sām sān kwèt wว̀n], a popular respect place to which Hakka people go to make a sacrifice to the gods at every Chinese festival. This community is known for a Hakka food called [tshôj kōn] which is a kind of preserved food made from vegetables pickled with salt and dried. They plant this vegetable in the garden and make preserved food to a recipe which is inherited from their ancestors. Today there are only a few families who are gardeners, because of globalization and because junk food is more popular among the younger generations. However, there are Hakka restaurants selling Hakka food in this community. They are famous not only within the community, but are also known to outsiders who come to eat there; they serve delicious and well-known Hakka dishes such as [kuájtiěw phàt tढī:n] 'fried Hakka style Chinese fresh noodle' [pân khów tshâw] 'a kind of Chinese soup ', etc. Even though this is not the original Hakka food from China, but has been influenced by other local traditions, the Hakka people in the area claim that it is Hakka style food. If local foods are cheaper and have more nutrients, the researcher should promote them to revive and maintain health and food security. Therefore, a research proposal on the revival of local food was developed.

Another project was developed because the researcher was interested in supporting capacity building of Hakka members on the website, which has no specific village like other ethnic groups. However, some members have Hakka networks such as the Hakka Association, which is located in many provinces in Thailand. These branches can be used as a resource, and can bring together stakeholders, because members of the website can collect data from the elderly and make connections with members of the Hakka Association from different areas. This is the first time a research project has targeted a group consisting of members of a website. This target group has very high abilities and are able to conduct research projects themselves, because they have their own data resources, including their families and themselves (Ungsitipoonporn 2013). However, a survey of their requirements was needed. The researcher used 
$<w w w . h a k k a p e o p l e . c o m>$ to promote the project and to recruit volunteer participants. The most important person is the web master, who created this website and wanted it to be a Hakka data resource. He was pleased and agreed to cooperate with the research team. The researcher also used personal contacts with other Hakka speakers who are not members of this website. Finally, the research project was developed and proposed for funding.

\subsection{The research process during the project}

Two research projects were supported by the Thai Health Promotion Foundation. For the first project, not only the Hakka group but also other ethnic groups who had the potential to conduct local food preservation were involved, such as Chong in Chanthaburi province, Lavua in MaeHongSorn province, Bru in Mukdaharn province, and Malayu in Yala province. The main objective was to explore and document local food wisdom in terms of how to prepare, how to cook, and how to use useful local food ingredients. The researcher promoted and encouraged the participants to give value and importance to local foods more than to junk food or western food. A Participatory Action Research (PAR) approach (Macdonale 2012) was applied in these two projects but was used differently in the activity methodologies. The concept of PAR combines two different approaches: participatory research and action research (Watters \& Comeau 2010: 5) were used in both projects. The methodology involved participants (Hakka people) and researchers, who were equal partners. This approach is suitable for participants who are regarded as experts in the traditional knowledge of their ethnic groups. The strengths of PAR are that the participants were active in making decisions throughout the research process, demonstrated and practised by themselves, and the researcher gained knowledge from the community together with the learners. At the beginning of the project, the researcher provided the participants with ideas on how to do research, because the Hakka group had never done any research before. Then the participants designed lists of activities that they wanted to do for local food revitalization. They specified purposes, outputs, and target groups but excluded language component. Finally, they took action according to 
timeline activities that had already been planned. Example activities were cooking Hakka food and explaining what distinguishes it from other local foods. The learners practised cooking as much as possible, and video recordings of cooking were made. Recipes of Hakka food were compiled. This process involved learning by doing. The Hakka women, who were instructors, prepared ingredients for each Hakka dish. The learners practised cooking after the instructor demonstrated how to cook. Then, they ate the food together. After that they talked about the history of Hakka food, related to their experience and beliefs. The learners then wrote summaries.
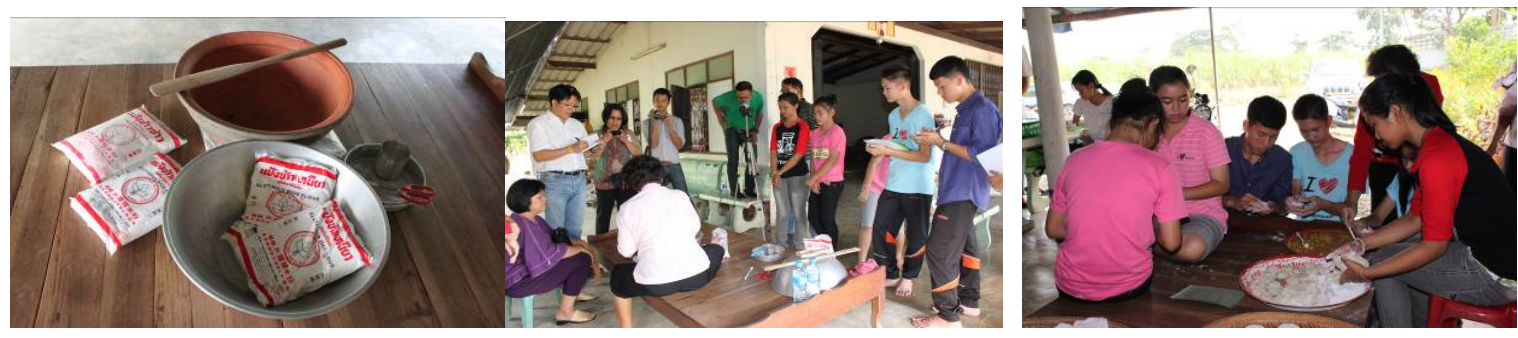

Figures 3-5. The process of cooking Hakka food: prepared ingredients; the instructor demonstrates; and the learners participate in cooking (pictures taken by Siripen Ungsitipoonporn, $14^{\text {th }}$ October 2012).

The second project was "Culture for Sustainably Promoting and Transmitting Local Wisdom via the Online Community". The main objective was to promote the capacity of Hakka speakers to preserve Hakka wisdom and to enhance their writing abilities, so that they could create a body of resources that would be available on the website: some members of the website wrote from their own experience while some interviewed Hakka elders. Before data collecting started, a brainstorming activity was organized by the researcher in order to encourage the participants to think about the topics that she was interested in writing about. These included Hakka history, food, vocabulary, traditions and beliefs, folk songs, etc. In order to reach the goal, several activities were planned during the project, as follows:

- Training the participants to write articles before starting to collect data. The researcher shared experience of academic writing with the participants, but she did not expect them to be academics. They hoped that at least they would get enough ideas to 
collect data and write interesting content. Some participants were afraid when they heard the words "research article" However, the researcher encouraged them that they would be able to do this because this was a practical research project and they were not going to be strict. For example, there was no limit to the length of the content and they could start by writing about the topics that they knew the best; if they interviewed Hakka elders they should acknowledge the consultant's name or other resources.

- Visiting four provinces where there were Hakka associations and Hakka speakers scattered living in those provinces in order to collect data, because the participants could then talk with Hakka elders and see the real situation in those areas. Some participants interviewed their relatives about the Hakka homeland and rituals. The participants then wrote about what they had learned by themselves as much as possible.

- Reliable content was checked and approved by academics who were familiar with the Hakka language and had Hakka origins; they also needed to be familiar with the Chinese orthography (Chinese characters), because some participants used Chinese characters in their articles such as translation content from Chinese to Thai. Meetings were organized between participants and these scholars in order to discuss and exchange opinions.

- All of the content produced was revised into one book and distributed via the website <http://www.hakkapeople.com/node/4573.html>.

\section{Results of the projects}

The outputs of the first project were video clips and a book of Hakka knowledge, containing the Hakka history of Huai Krabok village, the important Hakka customs and ceremonies one of the year, and Hakka style food recipes. The results revealed that the main risks for local food security were: (1) The impact of capitalism had an effect on the attitude and consumer behaviors of Hakka people; (2) Climate and environmental change were affecting the way of life in the community. For example, if they still plant vegetables for making pickled vegetable, their quality of life would be poor because the weather is 
hotter than in the past. They cannot produce good products, so they have to change from gardening to other occupations; (3) The target group, the younger generation, prefers junk food to local food. If the local restaurants still cook traditional food, they cannot sell it in the community, so they have to adapt the menu to consumer behavior. Besides that, there are a lot of convenience stores in every community, including in the rural areas. A further limitation of the Hakka group is that the younger generation go away from the village to study, so they are not interested in cooking by themselves. Although the elderly women would like to transfer Hakka food knowledge to the youth, there are no Hakka young people living in the community at the moment. Fortunately, some Hakka people from the website (their ages are between 40-55) wanted to join the project and learn with this community. The researcher tried to encourage non-Hakka youth to come and learn about Hakka food but they were not interested at all.

In terms of language use, the parent generation used the Hakka language very little in any activities. They used the Thai language to communicate with everybody because not everyone can understand Hakka. The researcher assumed that they cannot use Hakka language to explain something or to communicate well. From her observations, most of them can understand Hakka but they cannot speak; even when Hakka speakers from outside of this village addressed them in Hakka, they answered in Thai. They can only remember some Hakka words, such as [tshâw pân thiěw] 'fried noodle', [fûn] 'flour', [kîw tshôj pân] 'food made of rice flour mixed with tapioca flour filled with vegetables', [hăm tshôj] 'pickled vegetable', [tsū: niùk] 'pork', [kē:] 'chicken', [sûj] 'water', etc.

The major output of second project was a book of Hakka articles, written by more than ten Hakka members from the website hakkapeople.com. This project was quite satisfactory because the opportunity for documenting and writing about Hakka knowledge was opened up. It was not easy to encourage the website members to write articles based on their research. They were encouraged to write anything they wanted to. Then some of the members who had a university education were invited to read the articles and give some advice. Eventually, the participants were able to write at least one article (or story) per person. Some of them wrote short content but they wrote more than one topic. Some participants were not able to write even one article, but they acquired Hakka knowledge from the team. The strong point in this project was that the researcher 
was able to expand the network of the Hakka Associations in four provinces - Ratchaburi, Nakornratchasima, Burirum and Nakornsawan - because researchers circulated to organize research activities at the Hakka Association where the participants were members.

In terms of language use in the second project, the participants had more opportunities to hear and speak the Hakka language than in the first project, because they had time to talk with the elderly in each area. When the researcher took the van to the different Hakka Associations, the participants also talked a lot among themselves about Hakka history, custom, culture and ritual. Although they speak Thai more than Hakka, some participants said they can remember Hakka vocabulary. Most of them speak mixed language with Thai.

\section{Challenges of Hakka preservation in Thailand}

The most important problem for the intergenerational transmission of traditional knowledge was the younger generation's lack of awareness of their Hakka ancestors, because their parents never told them. Thus, they do not appreciate traditional food which relates to the history of their ancestors. Meanwhile, prepared foods are more convenient to buy at the market or at the supermarket. This is a serious challenge because prepared food has become a substitute for local food, which is cheaper and more nutritious. Although the research project promoted a revitalization of local food knowledge transmission to the next generation, few young people were interested in participating. As a result, the ongoing use of traditional food did not occur. The local food culture, which identifies the Hakka group, is at risk of disappearing in the near future. Another possible reason for this is that some Hakka dishes take more time and need too many steps to prepare. For example, [thèw ków pân] is composed of two parts: (1) mill rice, steam it in layers and cut into pieces (Figure 6), (2) fry these starch pieces with vegetables, bean sprouts and seasoning (Figure 7). At present, it is rarely possible to buy this Hakka dish in the market or the food store. 


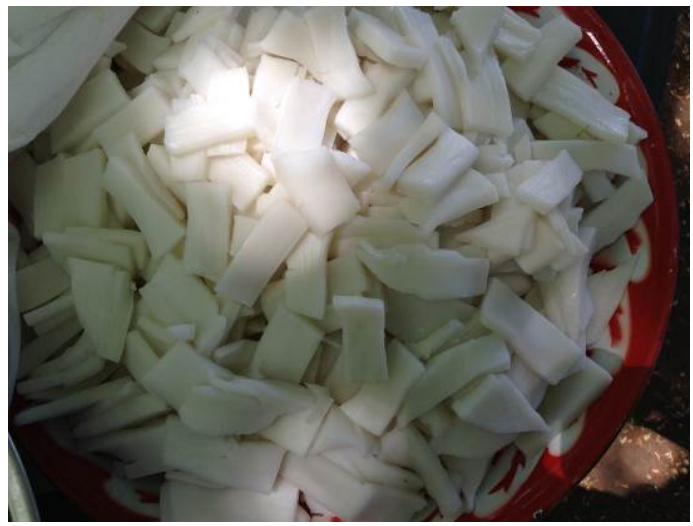

Figure 6. Starch pieces after steaming.

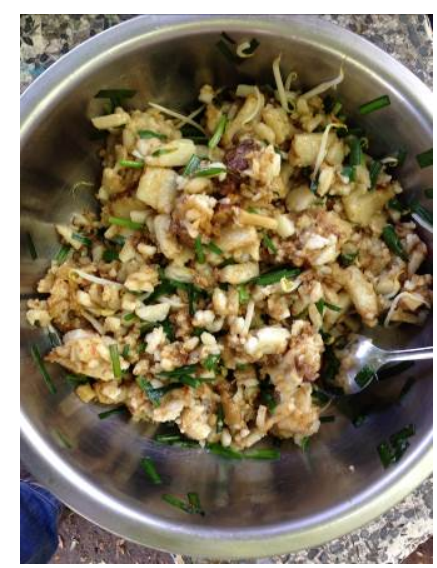

Figure 7. Fried starch pieces with other ingredients.

(Pictures taken by Siripen Ungsitipoonporn, $1^{\text {st }}$ June 2013.)

Most authors (Grenoble \& Whaley 2006; Fishman 2004; Thomason 2015) believe that linguists' participation can be helpful but that revitalization efforts need to come from within the community. No external person can revitalize a language as well as community members, so leadership must thus be provided by the community, and not by outside experts. The first project was not entirely successful because the participants were not enthusiastic. Their social status is quite good. They know that the Hakka language situation is unsafe but the decline of the language will not affect their life because they have already assimilated into the Thai population.

For the documentation of Hakka language and culture via the online community, there were some achievements which came from the volition of Hakka members who intended to write Hakka stories in order to disseminate traditional knowledge via the website. However, several problems and obstacles were encountered during the working process, such as the fact that most Hakka members did not know how to write reliably about their research. Some participants were elderly and could not use a computer so they needed someone to help them. Another challenge was that all of the Hakka members were volunteers, and most of them did not have enough time to get involved in every activity. The researcher needed to find a good strategy to encourage and empower them to the point that the project's objectives could be achieved. One important success is that they came to love and appreciate the high value of their ethnicity. The researcher 
received great assistance from the Hakka Association when conducting activities, and every Hakka speaker was keen to participate and help in the spirit of family support.

\section{Discussion and conclusion}

Over eight years the researcher has been encouraging Hakka people to document their local knowledge and transfer it on to the next generation. Two research projects were conducted and encountered several significant challenges. As Grenoble \& Whaley (2006: 6) stated, "the intergenerational transmission of a language is typically, and appropriately, used as a benchmark for whether a language will maintain its vitality into the indefinite future". Even in the Hakka village which was suggested by a Hakka speaker who had relatives in that community, there were no families where all of the generations, especially the children, had acquired the language. The domains and functions of language use are also important. Hakka is a non-dominant language and has no function in the community, so Hakka people use only the Thai language, even in the family domain.

However, there are some middle-aged individuals who do want to record their knowledge, and so they have created a website <www.hakkapeople.com $>$ through which to exchange ideas. Cyberspace is useful in terms being accessible to everybody can anywhere, anytime, as long as they have internet and computer. One member of this website said that his son had taught him to use the computer, and then he searched for the Hakka language. He knows a lot of Hakka vocabulary and he likes to answer any questions about Hakka if he can. One problematic issue is that several varieties of Hakka dialect are used to communicate on this website, and some members do not understand the pronunciation of others. They often argue about which dialect is the standard dialect. Therefore, the Thai-based writing system was not developed because they did not accept each other's varieties, so they write in the way the language is pronounced in their variety, rather than following consistent linguistic rules. Some members preferred to use Chinese characters but some wanted to write in the Thai script so that everyone could 
read and understand; still others wanted to use the Roman script. This made it difficult for people to agree on whether or how a writing system should be developed. Although there are only a few Hakka people interested in language preservation and revitalization, the researcher has not given up her plans to research further. One project plan is to cooperate with the Hakka elders in Thailand to transfer their intangible cultural heritage to the next generation.

Some linguists think that the Hakka people are a big ethnic group, scattered all over the world, but they cannot ignore the phenomenon of language shift and language loss in the near future. The researcher should not wait until Hakka language is severely endangered. When a language has no function in any domain, it will naturally disappear from the community. Therefore, the researcher will work towards preserving as much Hakka traditional knowledge as possible. From the research project "Culture for Sustainably Promoting and Transmitting Local Wisdom via the Online Community", she learned that the Hakka Association in Nakornratchasima province are interested in being empowered to pursue the next step towards language preservation. The Hakka speakers in that area have potential in many facets of language preservation. For example, there are a lot of members in the association and there is a Hakka youth association which is an important target group. If the researcher can find a suitable process for transferring the Hakka language and culture from the elderly to the younger generation, this will be a good opportunity. However, a challenge is that it is not easy to persuade the Hakka youth come and learn about traditional wisdom. The researcher should ask "What do they need?" It may be that modern technology and language documentation methods can be applied in this case, such as the use of video recordings and presentations from interviewing Hakka elder.

\section{References}

FISHMAN, Joshua (2004) "Language maintenance, language shift, and reversing language shift", in Tej K. Bhatia \& William C. Ritchie (eds.), The Handbook of Bilingualism, Oxford: Blackwell, 406-436. 
Grenoble, Lenore A. \& Lindsay J. Whaley (2006) Saving languages: an introduction to language revitalization, Cambridge: Cambridge University Press.

HINTON, Leanne (2001) The Green Book of Language Revitalization in Practice, Berkeley, California: Academic Press.

LuO, Yongxian (2005) "Sino-Tibetan Languages", in Philipp Strazny (ed.), Encyclopedia of Linguistics, New York; Oxford: Fitzroy Dearborn, 970-973.

MACDONALD, Cathy (2012) “Understanding Participatory Action: A Qualitative Research Methodology Research Option", Canadian Journal of Action Research, 13(2), 34-50. <http://journals.nipissingu.ca/index.php/cjar/article/viewFile/37/33> (accessed 15 February 2017).

MOSELEY, Christopher (ed.) (2007) Encyclopedia of the world's endangered languages, London and New York: Routledge.

PREMSRIRAT, Suwilai (2007) "Endangered Languages of Thailand", International Journal of the Sociology of Language, 186, 75-93.

PREMSRIRAT, Suwilai (2010) The role of MTB MLE in ECD and education: Experiences and challenges in Southern Thailand, Paper presented at MDGs Conference, November 2010.

PREMSRIRAT, Suwilai (2012) “Mahidol Model for the Preservation of Language Diversity: Thailand Experience", ASEM Language Diversity Forum Proceedings, September 2012.

PrEMSRIRAT, Suwilai (2017) “Endangered Language Speakers Networking: Thailand's Mahidol Model for Language Revitalization and Maintenance", in Takao Katsuragi \& John C. Maher (eds.), Minority Language Revitalization-Contemporary Approaches. Tokyo: Sangensha Publisher Inc.

THOMASON, Sarah G. (2015) Endangered languages: An introduction, Cambridge: Cambridge University Press.

UNGSITIPOONPORN, Siripen (2007) Phonological and acoustic analyses of the tone system of Hakka as Spoken in Bangkok, Thailand, Nakhon Pathom: Faculty of Graduate Studies, Mahidol University dissertation.

UNGSITIPOONPORN, Siripen (2011)" Language revitalization awareness in the Hakka group in Thailand", Jati, 16, 169-178.

UNGSITIPOONPORN, Siripen (2013) "The Virtual Hakka community: A new domain of revitalization", Jati, 18, 145-159.

UNGSITIPOONPORN, Siripen (2014) "Revitalization of Indigenous Hakka food: Challenges in Adversity" (in Thai), Silpakorn University Journal, 34(3), 43-64. 
UNGSITIPOONPORN, Siripen \& Kumaree LAPARPORN (2016) "Knowledge management (KM): Transmitting local wisdom of the Hakka community on-line-successes and challenges" (in Thai), Journal of Language and Culture, Research Institute for Languages and Cultures of Asia, Mahidol University, 35 (special issue), 203-225.

WATters, Julia \& S. ComeaU (2010) Participatory Action Research: An educational tool for citizenusers of community mental health service. Winnipeg, MB, Canada: University of Manitoba <http://umanitoba.ca/rehabsciences/media/par_manual.pdf>

UNESCO Atlas of the World's languages in danger.

$<$ http://www.unesco.org/new/en/culture/themes/endangered-languages/atlas-oflanguages-in-danger/>

Selected articles of Hakka traditional knowledge from the research project. 2014. <http://www.hakkapeople.com/node/4573.html> 